\title{
Histological and Immunohistochemical Study of the Possible Protective Effect of Ascorbic Acid on the Toxic Effect of Monosodium Glutamate on the Spleen of Adult Male Albino Rat
}

\section{Original Article}

\author{
Doha.S. Mohamed, Nesreen G. Abdelhaliem and Amal. M. Zakaria \\ Histology Department, Faculty of Medicine, Sohag University, Sohag, Egypt
}

\begin{abstract}
Introduction: Monosodium glutamate is widely used either as preservatives or enhancer of palatability. It is toxic to both human and experimental animals. Ascorbic acid is a natural antioxidant and has broad spectrum pharmacological properties. Aim of the work: The aim of the study was to determine the effect of monosodium glutamate on the structure of the spleen and to detect the efficacy of ascorbic acid to counteract these changes.

Material and methods : Thirty adult albino rats were divided equally into three groups. Group I was the control group; group II rats were intraperitonialy injected with monosodium glutamate $(4 \mathrm{mg} / \mathrm{kg} / \mathrm{day})$ for 2 weeks; and group III, were treated with the same previous dose of monosodium glutamate and $500 \mathrm{mg} / \mathrm{kg} /$ day ascorbic A for 2 weeks. At the end of the experiment, specimens from the spleen were taken and prepared for H\&E, Gomori silver stain and immunohistochemical stains (CD4 and CD68).

Results: In group II, there were loss of architecture of the spleen and significant increase in area $\%$ of the reticular fibers. Megakaryocytes were frequently noticed. There was a significant decrease in the number of both CD4+ T helper cells and CD68+ macrophages in comparison with the control group. In group III, a marked improvement in the structure of the spleen was observed, and the number of both CD4+ and CD68+ cells were significantly increased as compared to group II.

Conclusion: Monosodium glutamate had an immunosuppressive effect. Treatment with ascorbic acid was found to have protective role against this toxic effect.
\end{abstract}

Key Words: Ascorbic acid, spleen, mono sodium glutamate.

Received: 20 May 2016, Accepted: 30 April 2017

Corresponding Author: Doha Saber Mohammed, Tel.: 01007843762, Fax: 0934602963, E-mail: dohasaber@yahoo.com

ISSN: 1110-0559, March 2017, Vol. 40, No. 1

\section{INTRODUCTION}

Monosodium glutamate (MSG) is the sodium salt of the non-essential amino acid-glutamic acid ${ }^{[1]}$. It contains $78 \%$ of glutamic acid, $22 \%$ of sodium and water ${ }^{[2]}$. Monosodium glutamate is widely used as a food additive to improve the taste of food ${ }^{[3]}$. Despite its taste stimulation and improved appetite enhancement, some reports proved its toxicity ${ }^{[4]}$.

According to Schwartz (2004) the body uses glutamate as a nerve impulse transmitter in the brain and, there are glutamate responsive tissues in other parts of the body ${ }^{[5]}$.

High doses of glutamate were associated with various neuroendocrine abnormalities and neural degeneration ${ }^{[6]}$, and caused oxidative changes in different organ $\mathbf{s}^{[7]}$.
The immune and nervous systems are anatomically, physiologically, and functionally related to each other and share many similarities that cause interactions between them. It was proved that there was a direct link between the neuroendocrine and immune systems ${ }^{[8]}$ where the environmental stimuli promote a transient effect on the immune system through neuroendocrine pathways ${ }^{[9]}$. The immune system could be affected by many exogenous factors such as food and many pharmaceutical agents which lead to either immune stimulation or immunosuppression ${ }^{[10]}$.

Ascorbic acid (Ascorbic A) is a natural antioxidant that prevents the oxidative damage in body organs ${ }^{[11]}$. It is known to have a variety of biological and pharmacological properties. Since ascorbic acid together with MSG may be present in human diet so, it is necessary to evaluate its possible protective effect on MSG toxicity. 


\section{MATERIAL AND METHODS}

A total of 30 adult male albino rats (190 to 200 gms) purchased from the animal house of the Faculty of Medicine, Assuit University.. They were housed in clean properly ventilated cages with free access to food and water throughout the whole period of experiment. They were acclimatized to the environment at least two weeks before starting the experiment.

The Research Ethics Committee of the Faculty of Medicine, Sohag University, Egypt, approved the experimental protocol.

\section{Chemicals}

Monosodium glutamate and ascorbic acid were purchased from Cornil Laboratory Company, Cairo, Egypt. They were dissolved in distilled water.

The animals were divided into three groups 10 animals, each as follows:

Group I: were used as control group and injected with distilled water (4 $\mathrm{mg} / \mathrm{kg}$ /day) via the intraperitonial (IP) route for 14 days.

Group II: were injected intraperitonially with MSG dissolved in distilled water in a dose of $4 \mathrm{mg} / \mathrm{kg} /$ day for 14 days $^{[12]}$.

Group III: were received the aforementioned dose of MSG accompanied with ascorbic acid dissolved in distilled $(500 \mathrm{mg} / \mathrm{kg} /$ day $)$ IP for 14 days $^{[13]}$

By the end of the experiment, the animals were anaesthetized with ether and sacrificed. The spleen specimens were dissected and fixed in $10 \%$ formalin then paraffin blocks were prepared. Paraffin sections were done by a microtome (Leica RM2035) at $5 \mu \mathrm{m}$, mounted on glass slides and stained with:

Haematoxylin and eosin stain (H\&E) for general histological examination ${ }^{[14]}$. Gomori's Silver stain for demonstration of reticular fibers ${ }^{[15]}$.

Anti CD4 antibody (Spring bioscience; Pleasanton , USA,catalogue number; M3350; Monoclonal) for demonstration of T- helper lymphocytes.

CD68 antibody (Thermo scientific; Fremont, USA, catalogue number; E13920, Monoclonal) for demonstration of spleen macrophages ${ }^{[14]}$.

\section{Staining procedure}

Formalin-fixed, paraffin-embedded tissue sections ( $5 \mu \mathrm{m}$ thick) were deparaffinized and dehydrated including the positive control tonsil sections ${ }^{[16,17]}$. The endogenous peroxidase activity was blocked with $0.05 \%$ hydrogen peroxide in absolute alcohol for $30 \mathrm{~min}$. The slides were washed $5 \mathrm{~min}$ in PBS ofpH 7.4. To unmask the antigenic sites, sections were placed in EDTA buffer solution ( $\mathrm{pH}$ 8.0) in a microwave for $10 \mathrm{~min}$. The sections were incubated with 1200/ (CD4 and CD68) separately, except for the negative control. The slides were incubated for $1.5 \mathrm{~h}$ at room temperature. The slides were rinsed with PBS and then incubated for $1 \mathrm{~h}$ with anti-mouse immunoglobulins (secondary antibody) conjugated to peroxidase-labeled dextran polymer (Dako, Denmark). To detect the reaction, the slides were incubated in 3,3-diaminobenzidine for 15 min. The slides were counterstained by Haematoxylin , then dehydrated, cleared, and mounted by DPX.

\section{Morphometric study}

The mean number of CD4+ and CD68+ cells as well as the area of the reticular fibers were measured in five fields from each animal on high power field at magnification 400 from equally magnified images captured from the stained sections. The digital photos were captured in the Microscopic Photography Unit (Histology Department, Faculty of Medicine, Sohag University) using fifty different relevant fields from each animal group selected randomly. The measurements were performed using Digimizer PC image analysis software (Leica Q 500 MC program, Wetzlar, Germany).

\section{Statistical analysis}

The variables measured were recorded and tabulated. The mean and SEM were calculated for each animal group and then analyzed statistically. Calculations were carried out using Paired t test, SPSS, version 16 for windows (SPSS, IBM, Chicago, IL, USA) with $P$ values $<0.05$ regarded as statistically significant.

\section{RESULTS}

I- Histological and immunohistochemical examinations

The parenchyma of the spleen was consisted of lymphoid tissue (white pulps) that embedded in highly vascular matrix (red pulp) and marginal zones. The white pulp was formed of a sheath of many lymphocytes surrounding the central arteries (peri-arteriolar lymphatic sheath). The lymphoid follicles consisted of a large number of lymphocytes with condensed darkly stained nuclei. The red pulp was composed of branching and anastomosing splenic cords and blood sinusoids in between (Figs. 1 and 2).

Examination of MSG treated group (group II) revealed marked histological changes compared to the 
control group. Loss of architecture with highly atrophied white pulp appeared at focal areas of the spleen (Fig. 3).

There were degenerated lymphoid cells with pyknotic nuclei and vacuolated cytoplasm. The red pulp was widened and showed dilatation and congestion of blood sinusoids (Fig. 4). Some megakaryocytes could be observed (Fig. 5).

Examination of group III revealed restoration of splenic architecture in the form of lymphatic follicles of different sizes with well-defined marginal zones (Fig. 6). No megakaryocytes were observed (Fig. 7).

Silver staining technique demonstrated the reticular fibers of control group in the capsule, trabeculae and stroma (Fig. 8). Fine reticular fibers appeared in perivascular spaces and formed a branched framework throughout the red pulp. The reticular fibers were almost absent in the center of the white pulp but appeared at the margins and around the central arterioles (Fig. 9).

In group II the spleen sections showed an apparent increase in the amount of reticular fibers that manifested as thickened capsule and trabeculae. Dense network was present throughout the red pulp (Fig. 10).

In group III, the reticular fibers in capsule of the spleen, trabeculae and red pulp were more or less similar to those of the control group (Fig. 11).

Examination ofCD4 and CD 68 immunohistochemical stained sections of control groups showed a brownish cytoplasmic reaction in both T-helper cells and macrophages, respectively. Large number of CD4 positive cells were observed mainly in the white pulp.
Some cells were seen at the splenic cords of the red pulps (Fig. 12). Most of the CD68 positive cells were observed mainly in the red pulp, marginal zones, and along blood sinusoids with a relative absence in the white pulp (Fig. 13).

Examination of CD4 immunohistochemical stained sections of group II showed an apparent decrease in the number of CD4 positive cells as compared to the control group. CD4 positive cells appeared in white pulp, marginal zone and red pulp (Fig. 14). The CD68 positive cells also showed an apparent decrease in their number in comparison with the control group. They were located in marginal zone as well as red pulp (Fig. 15).

Examination of CD4 immunohistochemical stained sections of group III showed an apparent increase in the number of CD4 and CD68 positive cells, in comparison with group II (Figs. 16, 17). However, the numbers of these cells still appeared less than those in the control group.

\section{Statistical results}

There was a significant decrease in the number of CD4 and CD68 positive cells in group II in comparison with the control group. However, group III exhibited a significant increase and decrease in the number of these cells in comparison with group II and I, respectively.

The area $\%$ of the reticular fibers of group II revealed a significant increase as compared to control group while group III showed no significant change. There was significant decrease in the area \% in group III as compared to group as shown in II table 1 and (Histograms 1- 3).

Table 1: The mean number of CD4 and CD68 positive cells and area\% of the reticular fibers in different groups

\begin{tabular}{lcc}
\hline & $\begin{array}{c}\text { Control group } \\
\text { (group I) }\end{array}$ & $\begin{array}{c}\text { MSG-treated (group II) } \\
\text { MSG \& ascorbic A } \\
\text { (group III) }\end{array}$ \\
\hline Mean number of CD4 positive cells \pm SEM & $21.87 \pm 1.57$ & $5.87 \pm .56^{*}$ \\
Mean number of CD68 positive cells \pm SEM & $12.3 \pm 1.48$ & $4.23 \pm .55^{*}$ \\
Mean area \% of reticular fibers \pm SEM & & $27.74 \pm 1.6^{*}$ \\
\hline
\end{tabular}

$\mathrm{SEM}=$ standard error mean.

Significant when $P<0.05$.

* Significant difference in comparison with group I.

\# Significant difference in comparison with group II. 


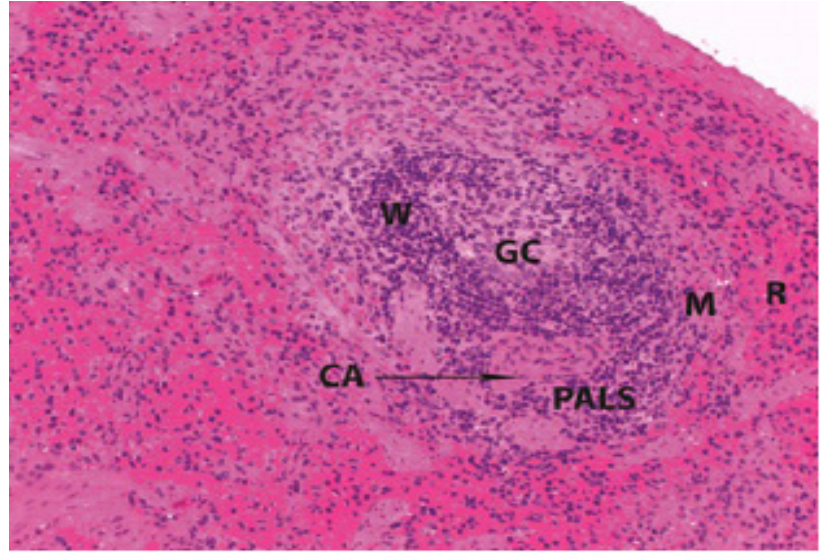

Fig. 1: A photomicrograph of a section in the spleen of control group. The white pulp contains well defined splenic lymphoid follicle (W) with central germinal center (GC), central arteriole (CA), periarterial lymphatic sheath (PALS) marginal zone (M) and red pulp (R).

$\mathrm{H} \& \mathrm{E} \times 200$

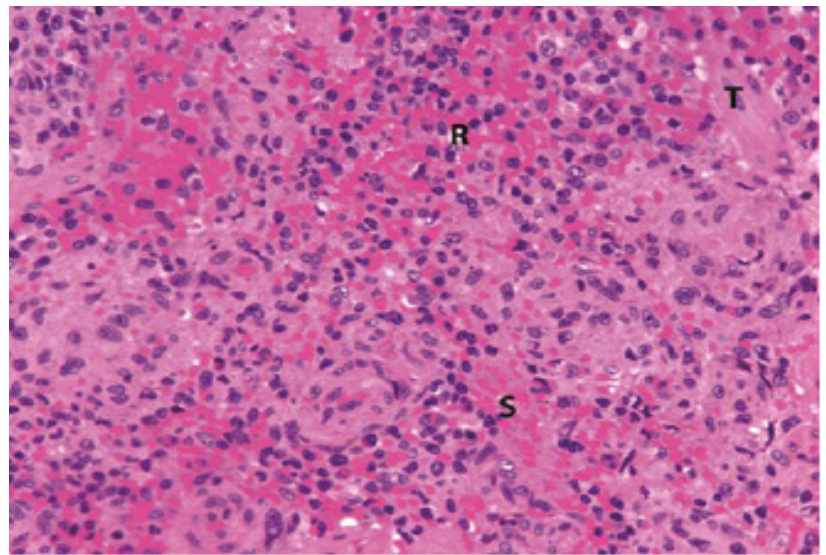

Fig. 2: A photomicrograph of a section in the spleen of control group showing; the red pulp (R) contains splenic cords of lymphocytes and blood cells and blood sinusoids (S) Note the splenic trabeculae $(\mathrm{T})$.

$\mathrm{H} \& \mathrm{E} \times 400$

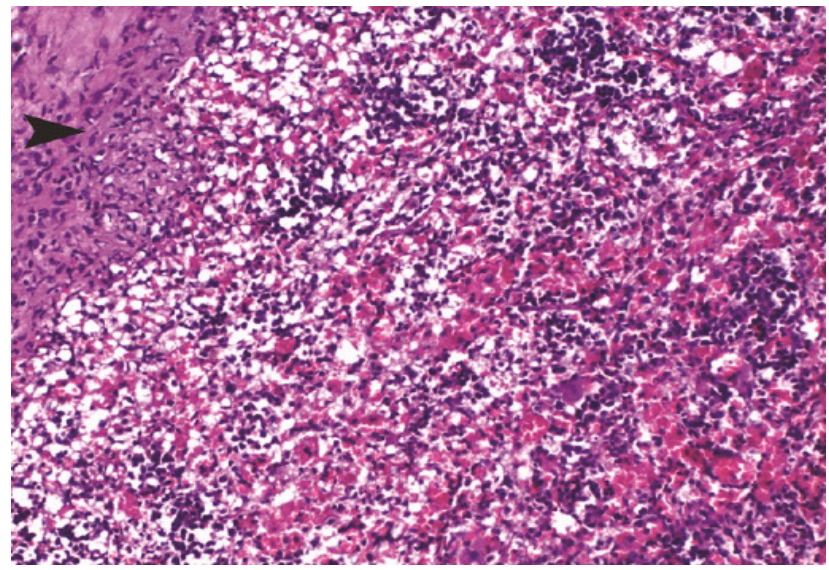

Fig. 3.A: Photomicrograph of a section in the spleen of group II showing; loss of architecture and highly atrophied white pulp. Note thick connective tissue capsule (arrow head).

$\mathrm{H} \& \mathrm{E} \times 200$

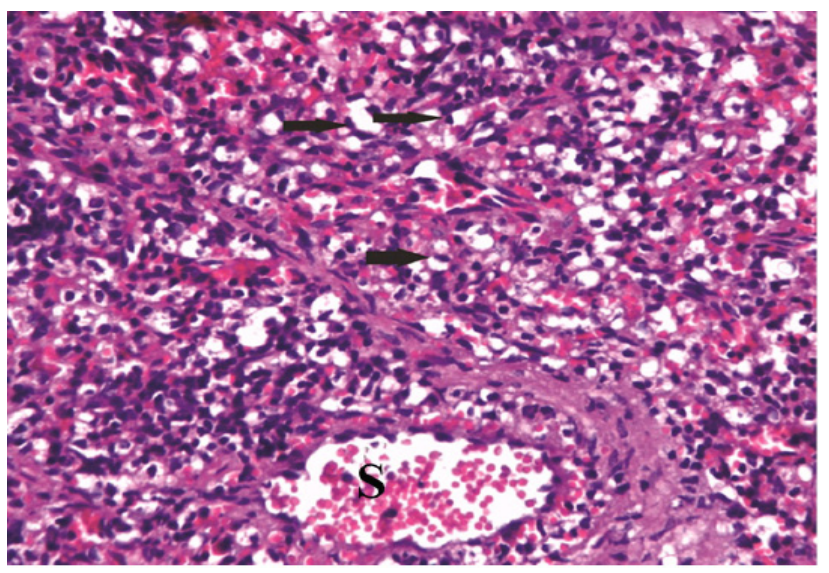

Fig. 4: A photomicrograph of a section in the spleen of group II showing; marked dilated and congested splenic sinusoids (S). Degenerated lymphoid cells with pyknotic nuclei and vacuolated cytoplasm (arrows) were frequently seen.

$\mathrm{H} \& \mathrm{E} \times 400$

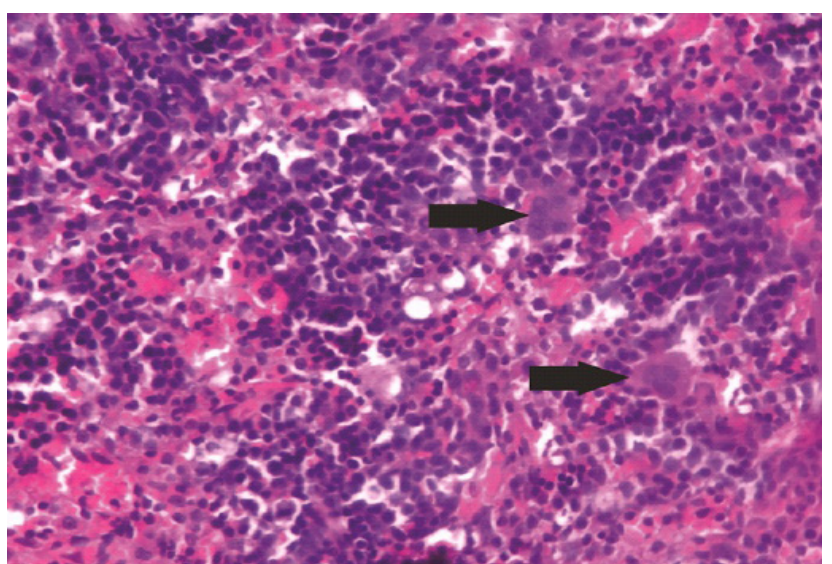

Fig. 5: A photomicrograph of a section in the spleen of group II showing megakaryocytes in the red pulp of spleen (Thick arrow).

$\mathrm{H} \& \mathrm{E} \times 400$

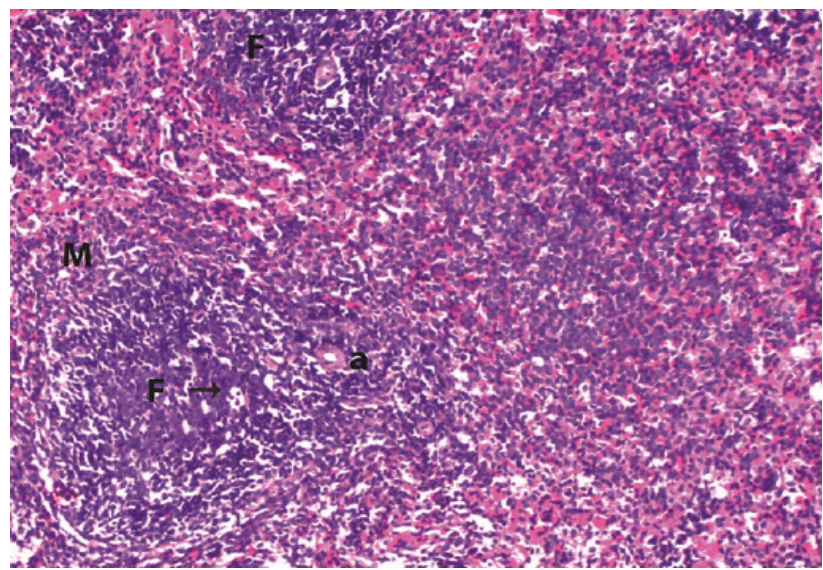

Fig. 6: A photomicrograph of a section in the spleen of group III showing; restoration of splenic architecture. Lymphatic follicles (F) formed of large number of lymphocytes (arrow) around the central arterioles (a) are seen. Note: well defined marginal zone $(\mathrm{M})$.

$\mathrm{H} \& \mathrm{E} \times 200$ 


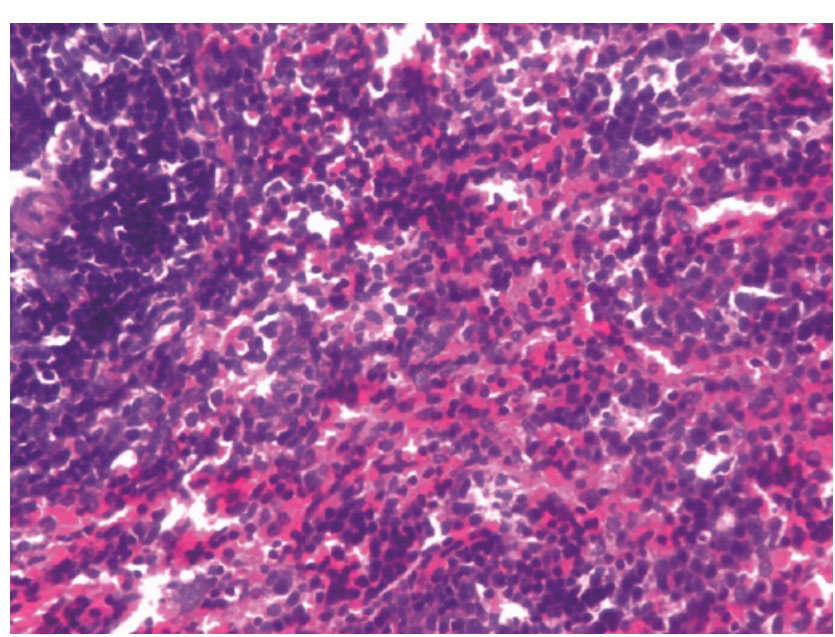

Fig.7: A photomicrograph of a section in the spleen of group III showing; no megakaryocyte in the red pulp.

$\mathrm{H} \& \mathrm{E} \times 400$

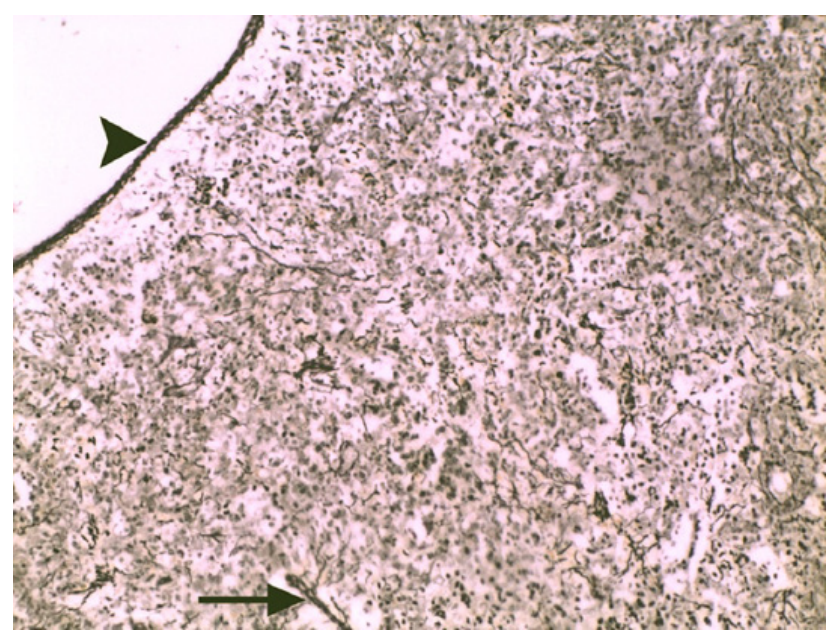

Fig.8: A photomicrograph of a section in the spleen of control group showing reticular fibers in the connective tissue capsule (arrow head), trabeculae (arrow) and stroma of spleen.

Silver stain $\times 200$

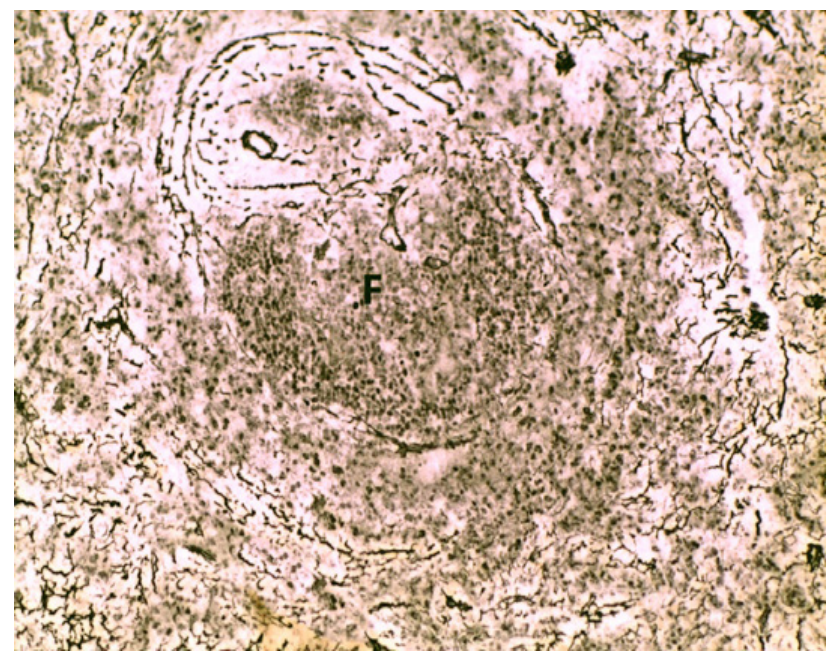

Fig. 9: A photomicrograph of a section in the spleen of control group showing the pattern of reticular fibers arrangement in lymphoid follicle $(\mathrm{F})$. Silver stain $\times 200$

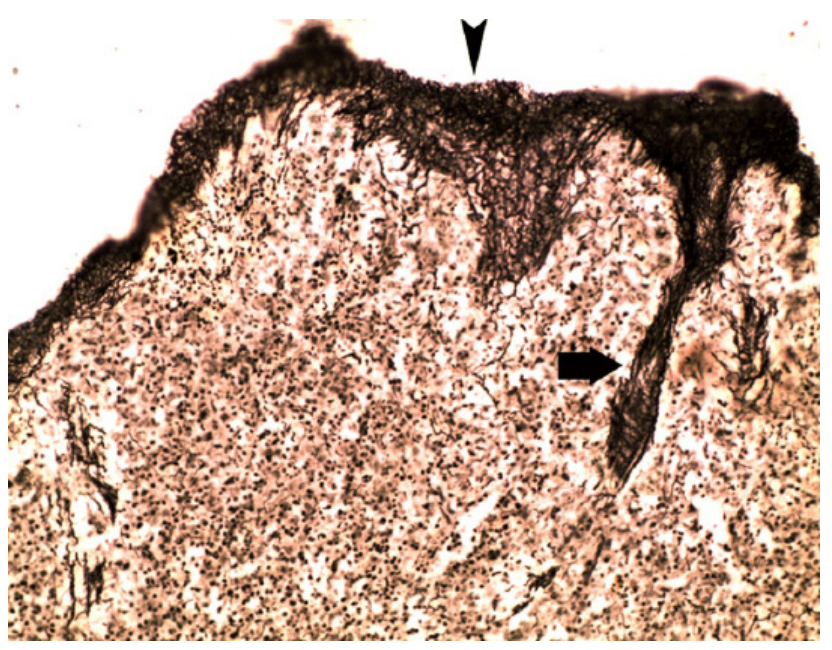

Fig.10: A photomicrograph of a section in the spleen of group II showing apparent increase in the reticular fibers of connective tissue capsule (arrow head) and trabeculae (arrow). Silver stainx

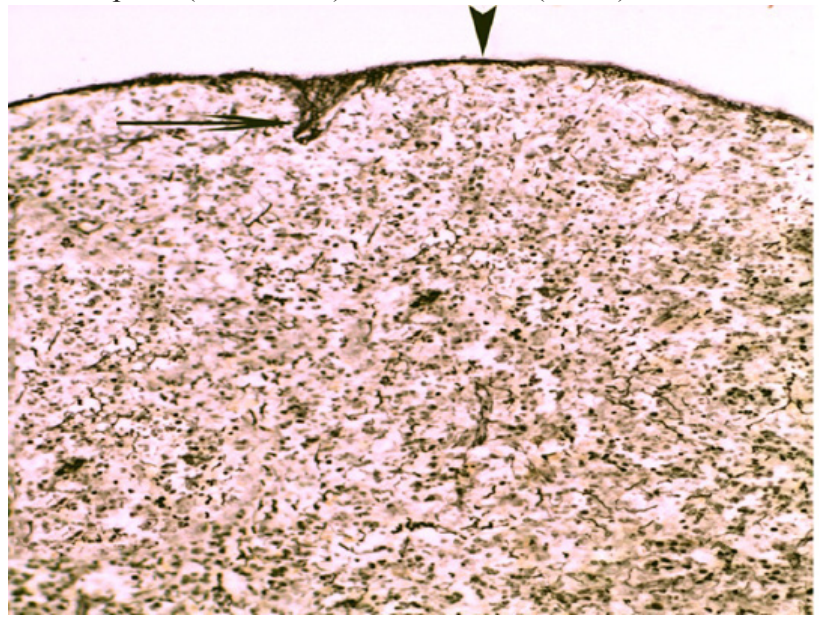

Fig.11: A photomicrograph of a section in the spleen of group III showing the reticular fibers in capsule (arrow head) and trabeculae (arrow) are more or less similar to control group.

Silver stain $\times 200$

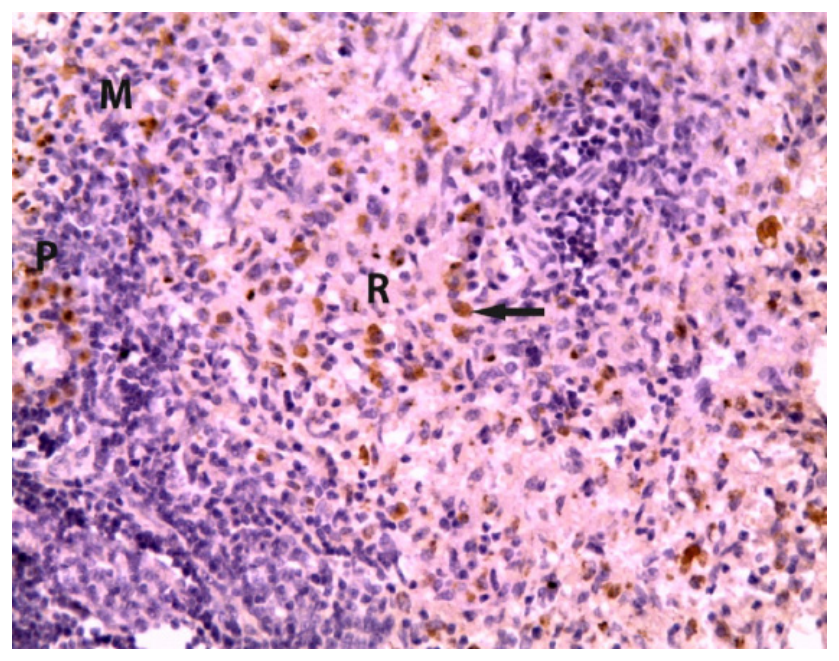

Fig.12: A photomicrograph of CD4 immunostained section in the spleen of control group showing CD4+ T-helper cells (arrow) appear mainly in periarterial lymphatic sheath $(\mathrm{P})$ of the white pulp, marginal zone $(\mathrm{M})$ and red pulp $(\mathrm{R})$.

$\times 400$ 


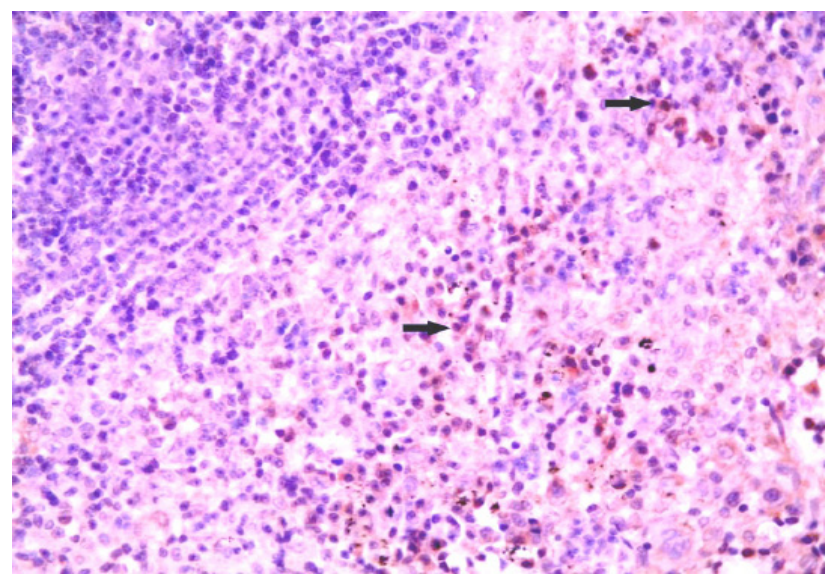

Fig.13: A photomicrograph of CD68 immunostained section in the spleen of control group showing negative reaction for CD68+ macrophages in the white pulp. The positive cells are mainly seen in the area of the red pulp (arrow).

$\times 400$.

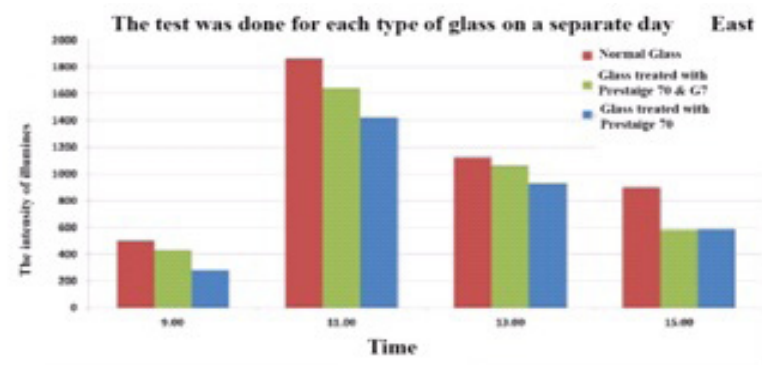

Fig.14: A photomicrograph of CD4 immunostained section in the spleen of group II showing apparent decrease in the number of CD4+ cells.

$\times 400$

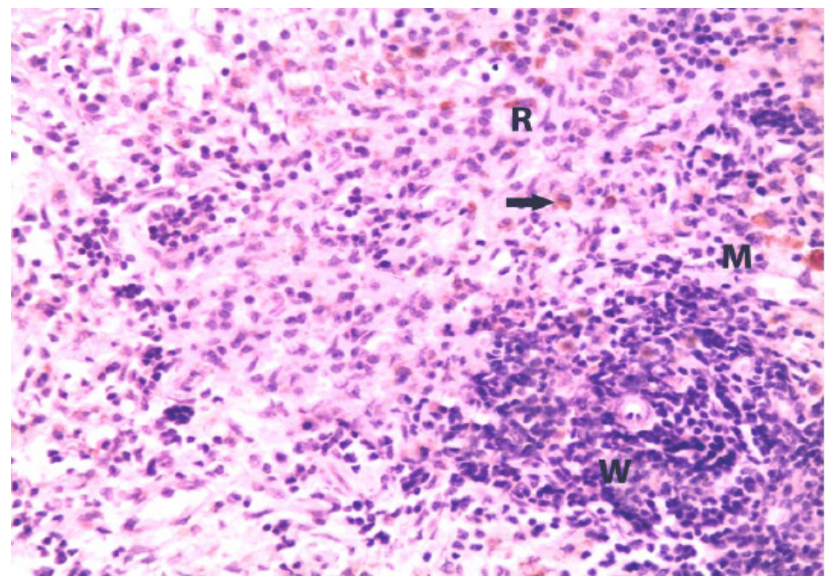

Fig.15: A photomicrograph of CD68 immunostained section in the spleen of group II showing an apparent decrease of CD68+ macrophages (arrow) in the marginal zones (M), and red pulp (R). Note: negative reaction in the white pulp (W).

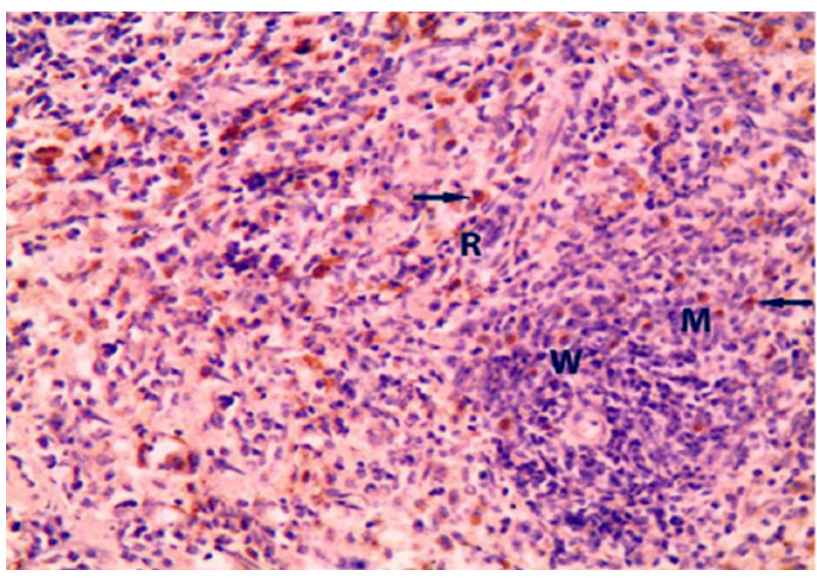

Fig.16: A photomicrograph of CD4 immunostained section in the spleen of group III showing an apparent increase in the number of CD4+ T helper cells (arrow) in the marginal zone (M), white pulp (W) and red pulp (R).

$\times 400$

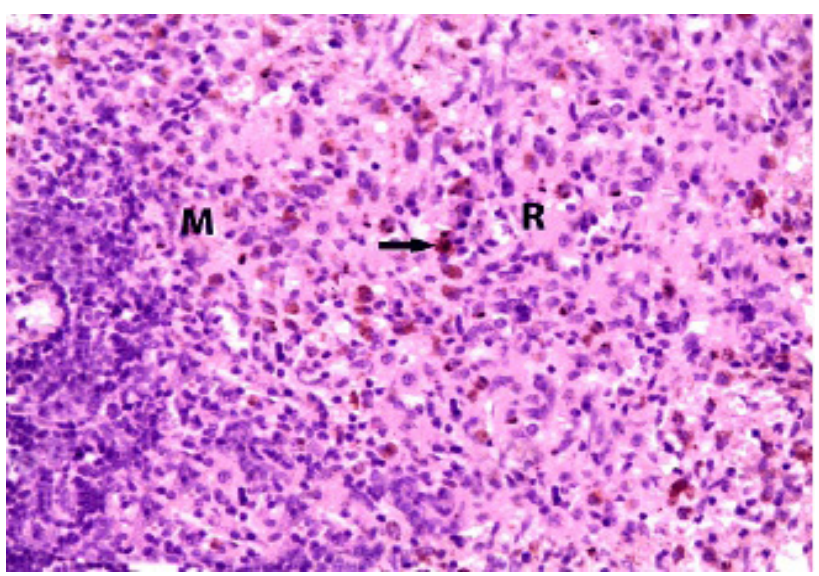

Fig.17: A photomicrograph of CD68 immunostained section in the spleen of group III showing apparent increase in the number of CD68+ macrophages (arrow) in the marginal zone (M), and red pulp $(\mathrm{R}) \times 400$.

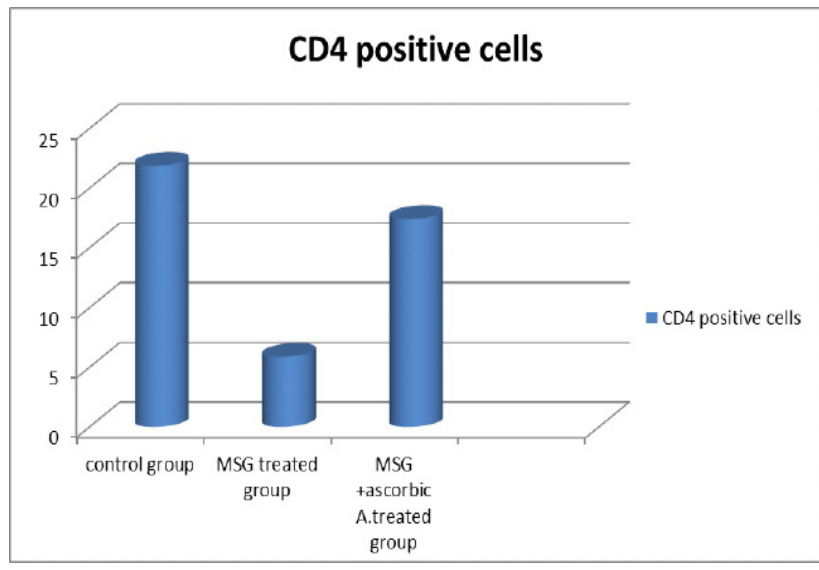

Histogram 1. 


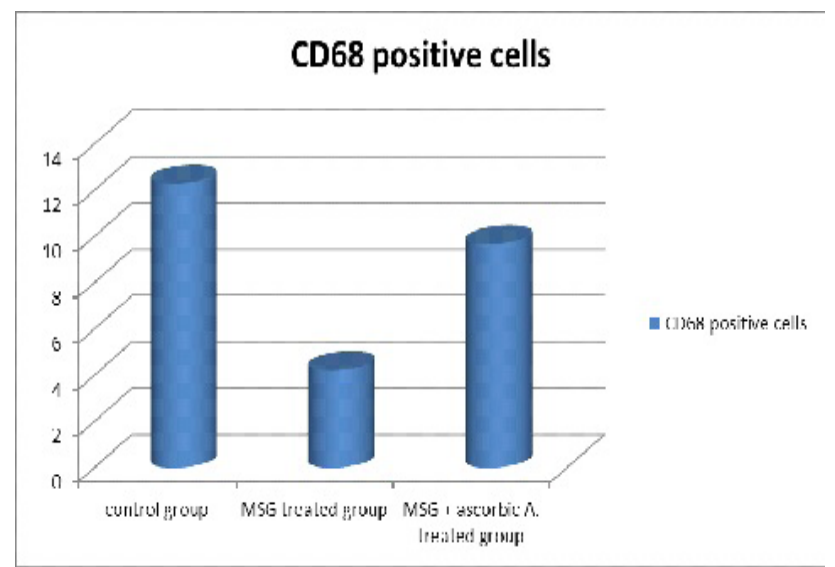

Histogram 2.

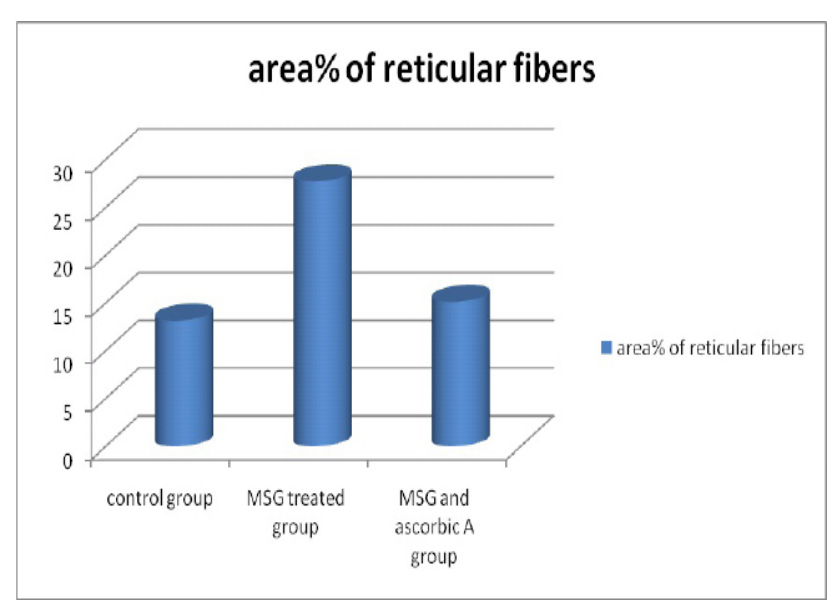

Histogram 3.

\section{DISCUSSION}

MSG is usually used as a flavor enhancer, which makes it one of the most applied food additives in the modern nutrition all over the world ${ }^{[18]}$. This research revealed that $\mathrm{MSG}$ induced histological alterations in the spleen structure of adult male albino rat. In MSG treated group atrophy of the white pulp was a prominent finding enforced with the proliferation of megakaryocytes in the red pulp as a compensatory mechanism, resulting from the degenerative changes. Most of the lymphocytes exhibited apoptotic changes as they had pyknotic nuclei and vacuolated cytoplasm consistent with the reported by Ajibade et al. 2015 ${ }^{[19]}$. Noteworthy, the oxidative stress caused by MSG induced DNA-damage, besides damage of lipids and proteins resulting in alterations in signal transduction, gene expression and apoptosis ${ }^{[20,12]}$.

Furthermore, glutamate receptors play a very important role in pathogenesis of disorders induced by $\mathrm{MSG}^{[21,22]}$. T lymphocytes express several types of glutamate receptors which control immune responses, cell activation, maturation and death ${ }^{[23]}$. Glutamate changes the activity of voltage-gated potassium channels leading to increase in the content of intracellular calcium ${ }^{[24]}$. Increased calcium influx leads to the excessive uptake of calcium into mitochondria, which can activate cell death by mechanisms such as the release of proapoptotic factors and increased generation of reactive oxygen species ${ }^{[25]}$.

In the present work, sinusoidal congestion and dilatation could be secondary to vascular obstruction. In context MSG caused endothelial injury that led to sequestration of red cells and platelets, impairment of the circulation and thrombus formation ${ }^{[26]}$. However, it might cause cardiovascular stress accompanied with a slowly-occurred mild cardiac failure and subsequent passive congestion ${ }^{[27]}$. This was associated with a significant increase in the surface area of the reticular fibers. The thickened capsule and trabeculae could allow the spleen to contract and eject the stored extra erythrocytes from the congested sinusoids ${ }^{[28]}$. This could be caused by increased fibrogenesis secondary to oxidative damage. It was suggested that lipid peroxidation might trigger and sustain an inflammatory response in which macrophages interact with matrix producing cells leading to expansion of the fibrotic tissue component. It could also induce over expression of fibrogenic cytokines, the key molecules in the mechanisms of fibrosis as well as increased transcription and translation of collagen ${ }^{[29]}$. These results coincided with other studies that reported renal fibrosis after MSG exposure ${ }^{[30]}$.

Immunohistochemical staining of CD4 and CD68 antibodies revealed significant decrease in their number. Collison and colleagues, (2012 found that MSG induced disturbance in hypothalamic-pituitaryadrenocortical axis ${ }^{[31]}$. Thus, it may lead to increased number of neurons secreting corticotropin-releasing hormone in the paraventricular nucleus of the hypothalamus, and the increased number of ACTHsecreting cells ${ }^{[32]}$. The increased glucocorticoids secretion led to suppression of the immune response and decreased lymphocyte proliferation by decreasing RNA synthesis and increasing protein catabolism in the lymphatic tissue ${ }^{[33]}$. Moreover, the oxidative stress induced by MSG could be responsible for the reduction in both T-lymphocytes and macrophages in the spleen $^{[26,34]}$. This is supported by the findings of Ayuob (2013), where aluminum-induced oxidative stress reduced the number and density of T-lymphocytes in the spleen of $\operatorname{rats}^{[35]}$. These results coincided with previous researches in neonatal rats whereas repeated doses of MSG resulted in changes of morphology and function of alveolar macrophages ${ }^{[36]}$.

In this current work, administration of ascorbic A with MSG ameliorated the previous pathological changes. This improvement included restoration of splenic architecture with a significant increase in CD4 
and CD68 positive cells. Furthermore, the reticular fibers exhibited non significant change in comparison to those of the control group, which may be attributed to the antioxidant ability of ascorbic A. As it is considered as one of the most important oxidative scavengers in the extracellular fluids ${ }^{[37]}$. The aforementioned results were in agreement with the previous studies ${ }^{[38,39]}$.

In addition, ascorbic acid was found to have immunostimulatory properties ${ }^{[40]}$. Accumulating evidence suggested that ascorbic acid can be concentrated inside the lymphocytes 80 times higher than in blood plasma. This could increase the ability of ascorbic acid to restore the number of $\mathrm{T}$ helper in the spleen ${ }^{[41]}$. It was proved that ascorbate plays a key role in both development and function of T-cells regulation $^{[42]}$. Pavlovic et al. (2009) confirmed this hypothesis as the treatment with ascorbic acid prevented the MSG-induced cytotoxicity in rat thymocytes by up-regulating $\mathrm{Bcl}-2$ protein expression ${ }^{[13]}$. This immunomodulatory effect of ascorbic acid was proven in liver and kidney ${ }^{[43]}$. Besides, ascorbic acid inhibited lipid peroxidation by enhancing the activity of endogenous antioxidant enzymes, glutathione peroxidase and glutathion-s-transferase ${ }^{[44]}$. Moreover, ascorbic A could prevent DNA damage ${ }^{[45]}$.

\section{CONCLUSION}

MSG led to histopathological changes in the spleen, which is likely to be ameliorated by the administration of ascorbic acid.

Subsequently, we recommend to add ascorbic acid regularly to meals and to restrict consumption of MSG containing products.

Further studies are needed to determine the effective dose of ascorbic A that restores the number of both $\mathrm{T}$ helper and macrophages.

\section{CONFLICT OF INTEREST}

There are no conflicts of interest.

\section{REFERENCES}

1. NHIC (Natural Health Information Center), (2008): http://www.Natural-HealthInformationCenter.com.

2. Samuels, A. (1999). The toxicity/safety of processed free glutamic acid (MSG): a study in suppression of information. Accountability inResearch6: 259 - 310 .

3. Vinodini، N.A. Nayanatara A. ' Damodar G.، Ahemed B. Ramaswamy C.R. ، Shabarinath and
Bhat M.R (2010): Effect of monosodium induced oxidative damage on rat testis . J. Clin . Med. 3: $370-373$.

4. Schwartz J R., 2004. In bad taste, the MSG " syndrome" MSG. the $5^{\text {th }}$ Annual Conference of the Weston A. Price Foundation.

5. Andrew O.E., Abieyuwa E. and Ferdinard A. (2007): Histological studies of the effects of monosodium glutamate of the fallopian tubes of adult female Wister rats. Med.Sci; 2:146- 149.

6. Moreno, G., Perelló, M., Gaillard, R. C., \& Spinedi, E. (2005). Orexin a stimulates hypothalamicpituitary-adrenal (HPA) axis function, but not food intake, in the absence of full hypothalamic NPY-ergic activity. Endocrine, 26(2), 99- 106.

7. Pavlovic V, Pavlovic D, Kocic G, Sokolovic D and Cekic S. (2007): Effect of monosodium glutamate on oxidative stress and apoptosis in rat thymus. Mol Cell Biochem. ; 303(1 -2):161 -166.

8. Mignini F, Streccioni V, Amenta F. Autonomic innervation of immune organs and neuroimmune modulation. Auton Autacoid Pharmacol 2003; 23:1-25.

9. Radek KA. Antimicrobial anxiety: the impact of stress on antimicrobial immunity. J Leukoc Biol 2010; 88:263-277.

10. Jain SP, Redasani VK, Kalaskar MG. Protective effect of Ginkgo biloba on ethanol-induced immunosuppression in rats. Eur $\mathrm{J}$ Exp Biol 2011; 1:83-89.

11. Nayanatara, A.K., Vinodini, N.A., Ahemed, B., Ramaswamy, C.R., Shabarianth, G. and Ramesh Bhat, M. (2008): Role of ascorbic acid in monosodium glutamate mediated effect on testicular weight, sperm morphology and sperm count, in rat testis. Journal of Chinese Clinical Medicine, 3:1.

12. Hala M. Ebaid and Hend M. Tag (2012):Monosodium Glutamate Toxic Effect on Spleen Structure and Potentiality of Recovery in Adult Albino Rats.Egypt. Acad. J. biolog. Sci.; 4(1): $1-8$.

13. Pavlovic, V., Pavlovic, D., Kocic, G., Sokolovic, D., Sarac, M., \& Jovic, Z. (2009). Ascorbic acid modulates monosodium glutamate induced cytotoxicity in rat thymus. Bratislavské lekárske listy, 110(4), 205- 209. 
14. Bancroft J D, Layton C and Suvarna S K. (2013): Bancroft's theory and practice of histological techniques, $7^{\text {th }}$ edition, Oxford: Churchill Livingstone Elsevier.

15. Puchtler H and Waldrop FW. (1978): Silver impregnation methods for reticulum fibers and reticulin: A re-investigation of their origins and specificity. Histochemistry Sep 15; 57(3): $177-187$.

16. Sada-ovalle, Talayero A., Barrera L. and SodaMerhy A." Functinality of CD4+ and CD8+ T cells from tonsillar tissue "2012 Clin. Exp. Immunol 168 (2) :200- 206.

17. Gianna Stent, Dean C Baylis, Megan Thomson and Paul U cameron " Heterogeneity of freshly isolated tonsil Denderetic cells demonstrated by intercellular markers, phagocytosis and membrane dye transfer "2002 Cytometry 48, $167-176$.

18. Garattini S. (2000). Glutamic acid, twenty years later. J Nutr.;130: 901S:-909S

19. Ajibade A.J, Fakunle P.B and Adetunji M.O (2015). Some effects of monosodium glutamate administration on the histo-architecture of the spleen and pancreas of adult Wistar rats $\mathrm{J}$ Pharm Biol Sci; 3(2): 39- 50.

20. Kannak K, Jain SK (2000): Oxidative stress and apoptosis. Pathophysiology; 7:153-163

21. Schlett, K. 2006. Glutamate as a modulator of embryonic and adult neurogenesis. Curr.Top.Med. Chem.; 6: 949-960.

22. Greenwood, S.M. and Connolly, C.N. (2007): Dendritic and mitochondrial changes during glutamate excitotoxicity. Neuropharmacology; 53: 891-898.

23. Kvaratskhelia E, Maisuradze E, Dabrundashvili NG, Natsvlishvili N, Zhuravliova E. (2009): $\mathrm{N}$-methyl-D-aspartate and sigma-ligands change the production of interleukins 8 and 10 in lymphocytes through modulation of the NMDA glutamate receptor. Neuroimmunomodulation; 16: 201- 207.

24. Miglio G, Varsaldi F, Lombardi G (2005): Human $\mathrm{T}$ lymphocytes express $\mathrm{N}$-methyl-D-aspartate receptors functionally active in controlling $\mathrm{T}$ cell activation. BiochemBiophys Res Commun; 338: 1875- 1883
25. Luetjens CM, Bui N Tand Sengpiel B (2000): Delayed mitochondrial dysfunction in excitotoxic neuron death: cytochrome $\mathrm{c}$ release and a secondary increase in superoxide production. $\mathrm{J}$ Neurosci; 20:5715-5723.

26. Hassan ZA, Arafa MH, Soliman WI, Atteia HH, Al-Saeed HF (2014) The Effects of Monosodium Glutamate on Thymic and Splenic Immune Functions and Role of Recovery (Biochemical and Histological study). J Cytol Histol 5: 283. doi:10.41727099.1000283-2157/

27. Konrad, S. P., Farah, V., Rodrigues, B., Wichi, R. B., Machado, U. F., Lopes, H. F., D'AgordSchaan, B., De Angelis, K. \&Irigoyen, M. C. (2012):Monosodium Glutamate Neonatal Treatment Induces Cardiovascular Autonomic Function Changes in Rodents. Clinics (Sao Paulo); 67(10), $1209-1214$

28. Bacha, W. J. and Linda, M. B. (2000): Color Atlas of Veterinary Histology. $2^{\text {nd }}$ Ed. Lippincott Williams \& Wilkins; Amazon com. Australia.

29. Poli, G. and Parola, M., (2006) oxidative damage and fibrogenesis. Free Radic. Biol. Med.; 22, 287- 305 .

30. Sharma, A. (2015). Monosodium glutamateinduced oxidative kidney damage and possible mechanisms: a mini-review. Journal of biomedical science, 22(1), 1- 6 .

31. Collison, K. S., Makhoul, N. J., Zaidi, M. Z., AlRabiah, R., Inglis, A., Andres, B. L., Ubungen, R., Shoukri, M. \& Al-Mohanna, F. A. (2012): Interactive Effects of Neonatal Exposure to Monosodium Glutamate and Aspartame on Glucose Homeostasis. Nutrition \& Metabolism; 9:58.

32. Cai D, Chen X, Liu Y. (1999):Effect of regulation of kidney-yin and kidney-yang on hypothalamuspituitaryadrenal-thymus axis in monosodium L-glutamate rats. ZhongguoZhong Xi Yi Jie He ZaZhi; 19:415-417.

33. Dharini S. (2007): Effect of AcoruscalamusLinn. and its active principle on noise stress-induced changes on immune system. Int J Biomed Adv Res 2012; 3:494-501.

34. SCHELMAN W.R., ANDRES R.D., SIPE K J., KANG E., WEYHENMEYER J.A. (2004): Glutamate mediates cell death and increases the Bax to Bcl-2 ratio in a differentiated neuronal cell line. Brain Res Mol Brain Res 128: 160- 169. 
35. Ayuob NN (2013):Can vitamin E and selenium alleviate the immunologic impact of aluminium on pregnant rats' spleens? Cell Immunol; 284:104 -110.

36. Liu W.K., Wong C.C. and Mak N.K. (2002) : Effects of neonatal monosodium-L-glutamate treatment on rat alveolar macrophages .ChemicoBiological Interactions;69,193- 201.

37. Singh RP, Sharad S, Kapur S.(2004): Free radicals and oxidative stress in neurodegenerative diseases .JIACM;5:218- 225.

38. Okolie NP, Iroanya CU. (2003): Some histological and biochemical evidence for mitigation of cyanide induced tissue lesions by antioxidants vitamins administration in rabbits. Food and Chemical Toxicology; 41(4):465-469.

39. Barros PS, Safatle AM, Queiroz I. (2004): Blood and aqueous humor antioxidants in cataractous poodles.Canadian Journal of Ophthalmology; 39:19-24.

40. Sahoo L., Choudhury T.G., Debnath C., Parhi J., Datta M., Purusothamman C.S. and Paniprasad K. 2016 Immunostimulatory Effect of Vitamin $\mathrm{C}$ on Hemato- biochemical Parameters of Labeo bata (Hamilton, 1822) Fishery Technology 53 (2016) : $59-63$.

41. Evans R.M., Currie L. and Campbell A. (1982): The distribution of ascorbic acid between various cellular components of blood, in normal individuals, and its relation to the plasma concentration. Br J Nutr. May; 47(3):473 -82. [PubMed] [Ref list].

42. Manning, J., Mitchell, B., Appadurai, D. A., Shakya, A., Pierce, L. J., Wang, H., .\& Spangrude, G. J. (2013). Vitamin C promotes maturation of T-cells.Antioxidants \& redox signaling, 19(17), 2054- 2067.

43. Farombi E. O. (2006): Monosodium GlutamateInduced Oxidative Damage and Genotoxicity in the Rat: Modulatory Role of Vitamin C, Vitamin $\mathrm{E}$ and Quercetin. Human \& Experimental Toxicology; 25: 251-259.

44. Blomhoff R. (2005): Dietary antioxidants and cardiovascular disease, Curr Opin Lipidol; 16: $47-54$

45. Manal S. T. and Nawal Al-Badr. (2012) :Adverse Effects of Monosodium Glutamate on Liver and Kidney Functions in Adult Rats and Potential Protective Effect of Vitamins C and E .Food and Nutrition Sciences; 3:651 -659.

46. Kashiwaya $Y$, Hasko $G$ and Liaudet L: Role of superoxide, nitric oxide and peroxynitrite in doxorubicin-induced cell death in vivo and in vitro. Am. J. Physiol. Heart Circ. Physiol. (2009) 296: H1466-83. 


\title{
الملخص العربى
}

\section{دراسة هستولوجية وهستوكيميائية مناعية للحماية المحتملة لحمض الاسكوربيك على السمية

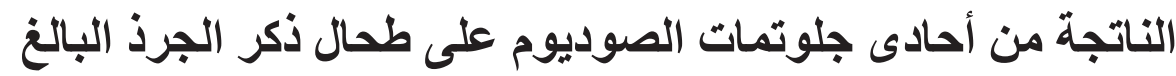

\author{
ضحى صابر محمد أحمد, نسرين جمال الدين عبد الحليم و أمل زكريا محمد
}

\section{قسم الهستولوجيا ـ كلية الطب - جامعة سوهاج - سوهاج - مصر}

الخلفية: يعتبر أحادى جلوتمات الصوديو ماده حافظه ومحسنه للطعم و هو ماده سامه لكل من الإنسان حيو انات التجارب.

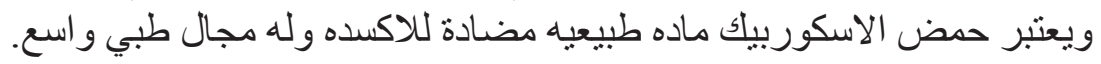
البحث: دراسة تأثير أحادى جلوتمات الصوديو مادئ طلى تركيب الطحال وكذلك معرفة مقدرة حمض الاسكوربيك لتقليل هذه التغير ات مات. الغرض من البحث: در اسة تأثثير جلو تاميد أحادى الصوديوم على طحال الفئر ان البيضاء البالغة والتأثير الوقائى المحتمل لحمض الأسكوربيك.

المواد و الطرق: لقد استخدم فى البحث ثلاثثون جرذ أبيض ولقد تم تقسيمهم لثنلاث مجمو عات. المجمو عه الاولى : استخدمت

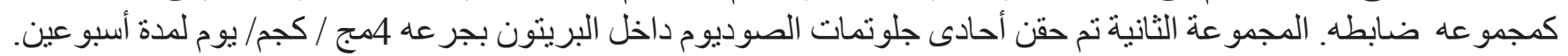

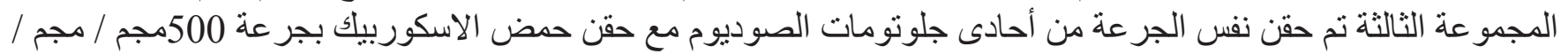

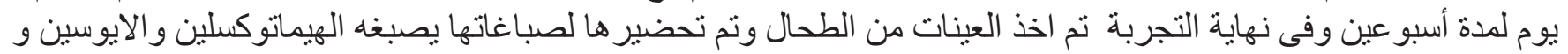
صبغة الفضة و المناعة الهستوكيميائيه النسيجيه. لكل من الخداية الخدايا التائيه المساعده و الخلايا البلعميه الكبيرة.

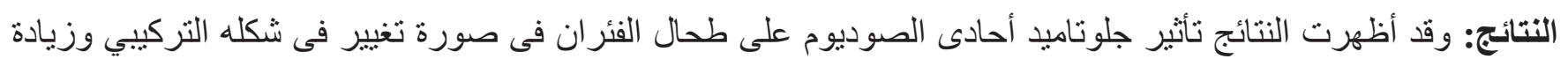

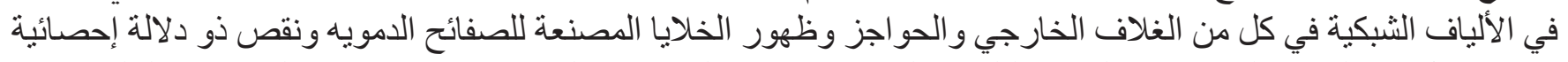

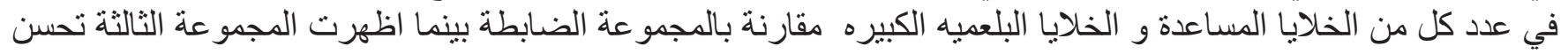

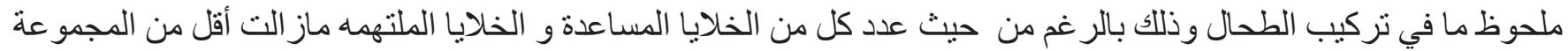

الضابطة.

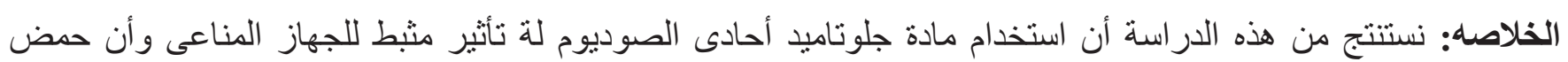

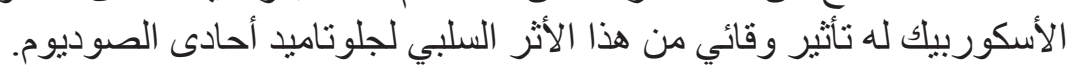

